JADEs: Journal of Academia in English Education

Volume 1 No 1, Juni 2020,(h.72-83)

https://journal.iainlangsa.ac.id/index.php/jades

\title{
An analysis of Students Ability in Skimming and Scanning in Reading Class of English Department FTIK IAIN LANGSA Bona Putra
}

\begin{abstract}
The purposes of this study were to find out the ability of students in Skimming and Scanning and to investigate how the students apply the procedure in Skimming and Scanning in Reading class. This study applied a descriptive qualitative approach. The writer used purposive sampling. The writer had nine respondents. The writer used documentation and observation as the instrument. Based on the results, indicated that in skimming, the students made a question, some also looked at the table of contents, they read or browsed at high speed, but some students were still affected to Look at reading topics. Then all students stopped when they found the topic they were looking for. but some students were not careful when text a reading. In scanning, the students also saw the table of contents first, but some students directly browsed to the page they wanted to find, besides, the students also read the background, and they also read the conclusions at a glance.
\end{abstract}

Keywords: Skimming and Scanning

\section{A. The Background of the Study}

There are two ways in reading, i.e skimming and scanning. Skimming is looking for general or main ideas. For example, when you read a newspaper, your eyes typically skim the headlines looking for a general article of interest. You might also skim a chapter or report to get a general understanding of what it is about. You probably also skim the menu of a restaurant you have never been to before to see what they offer. ${ }^{1}$ According to Ward Cramer, skimming is always used for a specific

1 Abby Marks Beale, Pam Mullan, The Complete idiot's Guide to Speed Reading: Time -Saving Strategies for Reading Faster and Remembering More (New York: Penguin 2008),18 
purpose- a purpose to be clearly established in the students' mind so that they will know what they are looking for. ${ }^{2}$.

Scanning is a technique used when searching for key words or ideas, usually when one knows what to look for. Scanning involves moving one's eyes quickly down the page seeking specific words and phrases. Scanning is also used to look for detail that may help answer questions. ${ }^{3}$

Skimming and scanning are two popular strategies of studying and information processing. They are used, but, most effective for sure confined cause. Skimming and scanning are speeding reading technique that is often done by readers. Both of these techniques are actually very functional, especially in daily activities.

Considering the explanation above, reading has an important role to help students understand the texts they read. From the initial observations made by the writer, it can be seen that in the faculty of English education, students have several problems in how to read. Therefore, it is necessary to conduct research to improve the reading skills, especially regarding skimming and scanning.

In this research, the writer would like to take object at English Department FTIK IAIN Langsa in reading class at reading lesson. Hence, based on the reason the writer would like to do the research entitled "An Analysis of Students' Ability in Skimming and Scanning in Reading Class of English Depaertment FTIK IAIN Langsa".

\section{B. LITERATURE REVIEW}

Skimming is verry fast reading. When you skim, you read to get the main ideas and few, but not all, of the details. To skim rapidly, you must

2 Ward Cramer, speed Reading for Better Grades (Portland: walch publishing, 1998), 65

3 Time, Verbal Ability and Reading Comprehension for the Cat and Other Mba Entrance Examinations ( with Cd), (New Delhi: Person Education India, 2010), 45 
leave out parts of an article or story. Skimming is a very useful skill. It will allow you to get information quickly from anything you read. Knowing how to skim will make you a better reader. ${ }^{4}$ Skimming is reading sections only, skipping to find the next section of interest. Concentrate on following the main ideas and blocking out detail. To read a chapter. It is a good idea to read the introductory paragraphs in full, then focus on topic sentences. ${ }^{5}$

Some situations that require the use of skimming are:

1. Examine a chapter in a book, before studying it seriously in order to get an idea about the general scope of that chapter. Sample a few pages of a novel or other type of writing to determine whether the writing is valuable reading.

2. Quickly examine an article on a controversial issue to find the author's views, without paying attention to the specific author's arguments.

3. Examine the reading material to assess whether the reading contains the type of information we are looking for.

4. Examine the reading material to determine whether the reading can be understood or is too difficult

Procedures of skimming

The steps of reading skimming to understand the main ideas in a reading are as follows:

a. Read the title. If it's an article, check the author, year of publication, and source used.

b. Read the introduction. If it is very long, only the first paragraph is read in full. Read the first sentence of each paragraph because usually

\footnotetext{
4 Edward, skimming and scanning: jamestown's reading inprovement(Westminster: Jamestown Publisher,2004), 1 64

5 Stephen McLaren, Essay Writing Made Easy (Singapore: Pascal Press, 2002),
} 
the first sentence is a statement that contains the main thoughts of the paragraph.

c. Read all heding and subheding. Heding, if presented together, will form an outline of the main topics in the reading.

d. See the picture, chart, or graphic that is included. Usually they are all included to emphasize ideas, concepts, or trends that are important. If you don't get enough information from the nursery or if you are working with reading material that does not have nursery, then read the first sentence of each paragraph.

a. Glance at the rest of the paragraph

1. See words or phrases in bold or italics.

2. Look for all the lists in the reading material. The author usually uses numbers, such as (1), (2), and (3) or may include marker words like first, second, one main cause, other causes and so on.

3. Look for things that are out of the ordinary or features highlighted in paragraphs such as words in capital letters, or some big numbers. ${ }^{6}$

\section{Scanning}

Maxwell in Diaz, S \&Laguado, J states that scanning, the students look for specific information within a text such as dates, names, places, among others and to defined as the ability to locate specific facts and details quickly, is regarded as a desirable reading skill and is taught in most development reading courses. ${ }^{7}$

Day and Bamford, scanning is the process of investigating, or checking by systematic search. In search and rescue operations, the scanner or

\footnotetext{
${ }^{6}$ Farida, Rahim, Pengajaran Membaca di Sekolah Dasar, (Jakarta: Bumi Aksara), 64

7 Diaz, Sindy\&Languado J.C, Improving Reading Skills Through Skimming and Scanning Techniques at a Public School: Action Research. Open Writing Doors, (online), Vol. 10, No 1, 2013, 138
} 
observer visually searches the search area for distress signals or accident indications by using a systematic eye movement pattern.

In scanning, the reader wants to examine closely using a regular plan or fixed without making a search for something looking at quickly without careful reading is often looking for a particular thing. The writer can find that scanning is the type of reading when reader wants to exam closely to look over quickly and systematically of left through hastilty. Step in scanning as follows:

a. Keep in mind at all times what it is readers are searching for. If they hold the image of the word or idea clearly in mind, it is likely to appear more clearly than the surrounding words.

b. Anticipate in what form the information is likely to appear, numbers, proper nouns, etc.

c. Analyze the organization of the content before starting to scan. (i) If material is familiar or fairly brief, you may be able to scan the entire article in a single search. (ii) If the material is lengthy or difficult, a preliminary skimming may be necessary to determine which part of the article to scan. d. Let your eyes run rapidly over several lines of print at a time. e. When you find the sentence that has the information you seek, read the entire sentence.

\section{RESEARCH METHODOLOGY}

This study used qualitative approach. Bogdan and Taylor define qualitative as research procedures that produce descriptive data with written verbal words from people and observable behavior. ${ }^{8}$ Therefore, the research method that emphasizes the aspect of in-depth understanding of a problem rather than looking at the problem for this generalization research confirms that qualitative descriptive is a

${ }^{8}$ Irwan, Dinamika dan Perubahan Sosial pada Komunitas Loka, (Yogyakarta: Deepublish, 2018), 53 
qualitative description of facts, data or material objects that are not in the form of a series of numbers, but in the form of language expressions or discourse through proper and systematic interpretation. ${ }^{9}$ Based on this statement, the researcher assumes that descriptive qualitative is to examine the case in a case case because the qualitative methodology believes that the nature of one problem will be different from the nature of other problems.

This research was conducted at IAIN Langsa, especially in english department of IAIN Langsa. Research subject is the person who is targeted in action research. ${ }^{10}$ The research subjects are respondents who serve as a sample in a study. Then researchers use purposive sampling in determining research subjects. The subjects of this study were five semeseter students in the reading class of the English department of IAIN langsa who were taking a reading class. Data collection that will be used by researcher is observation and documentation. In this observation, writer directly observe student learning activities and reading students who are observed or used as research sources. While The documentation is carried out by researchers by collecting written documents directly by students or unwritten from the research location relating to the research subject. The researcher uses descriptive analysis for data processing and analysis conducted to identify applications dyned understanding about.

\footnotetext{
9 Wahyu wibowo, cara cerdas menulis, (Jakarta: penerbit buku kompas, 2011), 43

10 A.A Ketut Jelantik, mengenal tugas pokok dan fungsi pengawas Sekolah Sebuah Gagasan, menuju perbaikan kualitas secara Berkelanjutan (Countious Quality improvement), (Yogyakarta: Deeppublish, 2018), 138
} 
Analysis of Miles and Huberman's version of the data, that there are three lines of activity, namely data reduction, data presentation, and drawing conclusions or verification. ${ }^{11}$

\section{FINDING AND DISCUSSIAON}

\section{1. skimming}

\begin{tabular}{|c|l|c|c|}
\hline No & \multicolumn{1}{|c|}{ Procedure of skimming } & participant & Percentage \\
\hline 1 & $\begin{array}{l}\text { The students make questions } \\
\text { about what they will look for } \\
\text { in a book }\end{array}$ & 9 & $9 / 9 \times 100=100 \%$ \\
\hline 2 & $\begin{array}{l}\text { The students browse the } \\
\text { table of contents or preface }\end{array}$ & 4 & $4 / 9 \times 100=44,4 \%$ \\
\hline 3 & $\begin{array}{l}\text { The students browse at high } \\
\text { speed every paragraph or } \\
\text { section }\end{array}$ & 6 & $6 / 9 \times 100=66,6 \%$ \\
\hline 4 & $\begin{array}{l}\text { The students Stop, when they } \\
\text { feel they find what they are } \\
\text { looking for }\end{array}$ & 9 & $9 / 9 \times 100=100 \%$ \\
\hline 5 & $\begin{array}{l}\text { The students read at normal } \\
\text { speed and understand } \\
\text { reading content }\end{array}$ & 5 & $5 / 9 \times 100=55,5 \%$ \\
\hline
\end{tabular}

Based on the explanation above, from the 5 procedures of skimming, the author tries to conclude that half of students used the procedure of skimming and some students are able to carry out the procedures described in the previous chapter. That can be seen from the following table:

${ }^{11}$ Husaini Usman dan Purnomo Setiadi Akbar, Metodologi Penelitian Sosial, (Jakarta: PT Bumi Aksara, 2009), 85-89. 


\section{2. scanning}

\begin{tabular}{|c|c|c|c|}
\hline No & The Procedure of the Scanning & Participants & Percentage \\
\hline 1 & $\begin{array}{l}\text { The students look at the table of } \\
\text { contents and preface at a glance }\end{array}$ & 9 & $9 / 9 \times 100=100 \%$ \\
\hline 2 & $\begin{array}{l}\text { The students briefly examine the } \\
\text { background of writing a book }\end{array}$ & 6 & $6 / 9 \times 100=66,6 \%$ \\
\hline 3 & $\begin{array}{l}\text { The students read the } \\
\text { introduction briefly }\end{array}$ & 5 & $5 / 9 \times 100=55,5 \%$ \\
\hline 4 & $\begin{array}{l}\text { The students search again in the } \\
\text { table of contents for important } \\
\text { chapters }\end{array}$ & 9 & $9 / 9 \times 100=100 \%$ \\
\hline 5 & The students read the conclusion & 6 & $6 / 9 \times 100=66,6 \%$ \\
\hline 6 & $\begin{array}{l}\text { The students glance at the } \\
\text { bibliography, index list, or } \\
\text { appendix }\end{array}$ & 5 & $5 / 9 \times 100=55,5 \%$ \\
\hline
\end{tabular}

By the data result explanation above, the writer tries to conclude that the student's ability to read scanning is based on the steps described in the previous chapter. It can be seen at the table percentage below:

3. Documentation Result of skimming

\begin{tabular}{|c|c|c|c|}
\hline No & Name of Participants & Score & Number of Questions \\
\hline 1 & HY & 6 & 10 \\
\hline 2 & FZ & 5 & 10 \\
\hline 3 & FT & 4 & 10 \\
\hline 4 & HR & 3 & 10 \\
\hline 5 & MA & 4 & 10 \\
\hline 6 & NY & 4 & \\
\hline
\end{tabular}




\begin{tabular}{|c|c|c|c|}
\hline 7 & RE & 6 & 10 \\
\hline 8 & RAD & 3 & 10 \\
\hline 9 & RA & 3 & 10 \\
\hline
\end{tabular}

Based on the above table, it can be said that HY and RE can answer questions about skimming questions with the score 6 of 10 . The participant FZ got the score 5 of 10. FT, MA, and NY got the score 4 of 10, while HR, RAD and RA only got the score 3 of 10 . The writer found that students were still weak in understanding procedures or techniques of skimming. However, some of them had already understood about some procedures of skimming. In this case the students were still dominated by several techniques in answering questions about skimming.

4. The Results of Documentation in Scanning were as follow:

\begin{tabular}{|c|c|c|c|}
\hline No & Name of participants & score & Number of Questions \\
\hline 1 & HY & 8 & 5 \\
\hline 2 & FZ & 7 & 5 \\
\hline 3 & FT & 6 & 5 \\
\hline 4 & HR & 6 & 5 \\
\hline 5 & MA & 7 & 5 \\
\hline 6 & NY & 6 & 5 \\
\hline 7 & RE & 8 & 5 \\
\hline 8 & RAD & 5 & 5 \\
\hline 9 & RA & 6 & \\
\hline
\end{tabular}

Based on the results above, the writer can say that 2 students got the score 8 of 5.2 students got the score 7 of 5 . And 4 students got the score 6 of 5 . However, only 1 student got the score 5 . 
Skimming is a technique of reading at high speed, which is useful for finding important things or becoming the main idea in a reading. In this technique, there were 5 items students must do to find the main ideas in a reading. Judging from the results of this study there were still many students who were less able to understand about skimming. However, the writers found that some students were still confused in doing so although only a few of them performed the procedure from skimming perfectly from the first step to the last step is done well. In addition, there were also some students who only took the first, third and fourth steps, but not the second and fifth steps. Some of them also took only the first, fourth, and fifth steps. Judging from the results of this study there were still many students who were less able to understand about skimming.

Next is scanning. Scanning is a technique of reading quickly to get information without reading other types of reading. Usually, scanning is used to look up phone numbers, look up words in a dictionary, look for entries in an index, look for statistics and look for television shows. Scanning also has 6 procedures to find what you're looking for when reading scanning. Based on the analysis, the writer found that the students also were confused in understanding about scanning. Some students did the first, fourth and fifth procedures. Several other students also performed the first, second, and fourth procedures. Then, there were some students who almost all procedures, they are first, third, fourth, fifth and sixth. Howover, there were two students who really understood the challenge of scanning. They did the procedure of scanning completely. It can be said that more than half of students who still did not understand and carried out the procedure of scanning completely.

After the researcher do the research, researcher concluded some students in reading Class of English Department having problems with skimming 
and scanning. The most reason was lack of carefulness. They cannot understand the procedures and techniques to make skimming and scanning. Even though some students still confused with the different of skimming and scanning.

\section{E. CONCLUSSION}

The writer draws some conclusion as follows:

1. In skimming, the students were still confused in understanding about skimming. It was proven that only 2 participants of 9 participants was able to carry out the steps of skimming correctly and regularly. From the results of the documentation the writer also found that only 2 participants were able to have a score of 6 out of 10 questions. Besides the students had a score of 5 even below 5 of 10 questions. In scanning, some students were still confused or lack understanding in scanning. It was proven that only 3 participants of 9 participants were able to carry out 6 procedures of scanning in an orderly and perfect manner. However, from the results of the documentary, the writer found that the students were able to read scanning with the questions given by researchers. Although only a few students were still less capable. It was proven that 8 participants of 9 participant had a score of 8.7 , and 6 and only 1 participant has a score of 5 .

2. In skimming, the writer described the five procedures of skimming. The first procedure was all students did it (100\%), the second procedure, only 4 participants of 9 participants $(44,4 \%)$, the third procedure, only 6 participant of 9 participants $(66,6 \%)$, the fourth procedure, all students $\operatorname{did} \mathrm{it}(100 \%)$, the fifth procedure, only 5 participants of 9 participants (55,5\%). In scanning, the writer described the use of the six procedure of scanning. The first procedure was all students did it $(100 \%)$, the second procedure, more half of students used this procedure $(66,6 \%)$, the third procedure, only 5 participants of 
9 participants used this procedure (55,5\%). The fourth procedure, all students used this procedure $(100 \%)$. The fifth procedure, only 5 participants of 9 participants $(55,5 \%)$

\section{Bibliography}

Cramer Ward, speed Reading for Better Grades, Portland: walch publishing, 1998

Edward, skimming and scanning: jamestown's reading inprovement, Westminster: Jamestown Publisher,2004

Irwan, Dinamika dan Perubahan Sosial pada Komunitas Loka, Yogyakarta: Deepublish, 2018

Jelantik A.A Ketut, mengenal tugas pokok dan fungsi pengawas Sekolah Sebuah Gagasan, menuju perbaikan kualitas secara Berkelanjutan, Countious Quality improvement), (Yogyakarta: Deeppublish, 2018

Marks Beale Abby, Pam Mullan, The Complete idiot's Guide to Speed Reading: Time -Saving Strategies for Reading Faster and Remembering More New York: Penguin 2008

McLaren Stephen, Essay Writing Made Easy, Singapore: Pascal Press, 2002

Rahim Farida, Pengajaran Membaca di Sekolah Dasar, Jakarta: Bumi Aksara

Sindy Diaz \&Languado J.C, Improving Reading Skills Through Skimming and Scanning Techniques at a Public School: Action Research. Open Writing Doors, (online), Vol. 10, No 1, 2013, 138

Time, Verbal Ability and Reading Comprehension for the Cat and Other Mba Entrance Examinations (with $\mathrm{Cd}$ ), (New Delhi: Person Education India, 2010), 45

Usman Husaini dan Purnomo Setiadi Akbar, Metodologi Penelitian Sosial, Jakarta: PT Bumi Aksara, 2009

wibowo Wahyu, cara cerdas menulis, Jakarta: penerbit buku kompas, 2011 